\title{
A Delicate Mosaic: The Future of Muslims in Canada
}

\author{
Sahar Khelifa*
}

\begin{abstract}
Islam has had a long and, recently, very contested history in Canada. Studies after 9/11 show an increasingly negative view towards Islam and Muslims in Canada. The presence of Canadian Muslim diaspora, supposed clashes between Islam and the West, and the rise of Islamophobia and counter anti-Islamophobia movements have strained Muslim integration efforts and challenged Islam's place in Canadian society, testing long-standing Canadian values and beliefs about multiculturalism, democracy and pluralism. This paper addresses the question of Canadian-Muslim integration, looking briefly at the history of Muslims in Canada, the issues they face today, and current events regarding Islam's place in Canadian society, including Bill 94 and the niqab debate during the 2015 Canadian election. The paper also proposes a process where Muslim communities, the Canadian government and the public can work together to build understanding and resolve differences in order to move forward as a country.
\end{abstract}

Keywords: Islam, Muslims, Canada, Canadian Muslims, integration, multiculturalism, immigrants, Islamophobia, antiIslamophobia, policy of recognition, Islam vs. the West, Bill 94, niqab

"It is not our differences that divide us. It is our inability to recognize, accept, and celebrate those differences." -Audre Lorde

\section{Preamble}

Life after 9/11 has been difficult for everyone, but it has posed a particular difficulty for Muslims. Since the attacks in 2001, Western public view of Islam and Muslims has grown increasingly negative. In Canada, a $2009^{1}$ study by Angus Reid found that 46 percent of Canadians and 68

\footnotetext{
${ }^{1}$ No data on Canadian public views on Islam and Muslims could be found before $9 / 11$ or immediately afterwards, which would have provided for richer data and analysis.
}

percent of Quebecers held unfavourable views of Islam (Geddes). Four years later in 2013, the same study was conducted and found 54 percent of Canadians and 69 percent of Quebecers held unfavourable views of Islam, an increase of nearly 10 percent for Canadians outside of Quebec; Canada's view on Islam is getting worse (Geddes). What is more, the study also found that when comparing Canadian views on Islam with other religions including Sikhism, Hinduism, and Judaism, Islam was the only religion to hold negative views by the majority of the country, and by a significant margin; for instance, in $2013,15 \%$ of Canadians outside of Quebec held less favourable views of Islam than Sikhism, the second least tolerated religion in Canada (Geddes).

If Canadian public perception of Islam is worsening, it is not surprising that Islamophobia, or fear of Islam and

\footnotetext{
*Department of History, College of Arts and Science, University of Saskatchewan, Saskatoon, SK, Canada
} Correspondence: sak146@mail.usask.ca 
Muslims, is on the rise as well (Hanniman 273). Recent years have increasingly seen Muslims become the target of hate crimes, discrimination, racial profiling, and Islamophobic policies in Canada and abroad (Perry and Poynting 1-2; Hanniman, 273-274). In addition, Canadian media coverage of Islam and Muslims has been alarmingly negative, as have various government actions (or inactions) towards the Canadian Muslim community (Perry and Poynting 4-6). As a result of the negative atmosphere created by current policies and media coverage, the "permission to hate" Islam and attack or demoralize Muslims is now possible in Canada, a country that has long been valued for its tolerant and multicultural social values (Perry and Poynting 1).

If Canadian Muslims today face increased intolerance in a country with strong democratic and pluralistic ideals, what will the future hold for Muslims in Canada? This paper attempts to answer this question by affirming that despite the bleak projection that may become the future for Muslims in Canada, peaceful coexistence and integration is possible if Muslims reevaluate Islam in the Canadian context and if the Canadian government and public can engage with and accommodate the needs of Muslim citizens more effectively.

This paper discusses problems and solutions to Canadian-Muslim integration. The paper begins by providing a brief historical and demographic account of Islam and Muslims in Canada, followed by a thorough discussion of three barriers to Canadian-Muslim integration: Canadian Muslim diaspora, conflicts between Islamic and Western values, and Islamophobia, especially in light of the niqab controversy Canada has witnessed recently. The second part of the paper suggests solutions to these problems by discussing approaches to minority integration and suggesting a model of integration that can help serve the needs of both Muslims and non-Muslims in Canada today and in the future; the model outlines the roles to be played by both the Muslim community and the larger Canadian community and government. Finally, the paper ends with personal reflections on being a Canadian Muslim and hopes for the future, as well as some brief comments on two recent events in Canada: the Quebec shooting and the passing of Motion 103 in Canadian Parliament.

\section{Looking Back: Canadian Muslim History and Demographics}

Muslims first arrived in Canada between the 1850 and the 1870 s (Kazemipur 24). The first Muslims in Canada, a Scottish couple by the name of James and Agnes Love, arrived in Canada in 1854 and their son, James Love junior, born that same year, was the first native-born Canadian Muslim (Zine 4). The early Muslim community was small and experienced little growth (5). By the early 1900s, there were 1500 Muslims in Canada, the majority of whom were Turkish and Syrian immigrants (5). Early Muslims mainly settled in the Canadian prairies, including Saskatchewan, and worked as farmers, fur traders, shopkeepers and railway workers (5). The first mosque in Canada was built in 1938 in Edmonton and would have likely housed a small congregation given the Muslim population at the time (Rehman and Siddiqui 43; Kazemipur 24).

During World War I, as a result of Canada's racially exclusive policies, Muslim immigrants were not allowed into the country and many, mainly Turkish immigrants, were deported back to their countries of origin under the pretence of being enemy aliens (Zine 5i Kazemipur 24). Muslims were certainly not the only minority group to face discrimination in Canada's early days. In fact, they were only one of a long list of rejected and mistreated immigrants, like the Chinese in 1907 who were criticized by politicians for taking over Vancouver and whose businesses and houses were attacked by angry citizens; the 376 immigrants from India who were refused entry into Canada in 1914; the Mennonites, Hutterites, and Doukhobors on the basis of their "peculiar habits, modes of life, and methods of holding property" in 1919 (as cited in "Not our proudest moments" 8); the Communists in the 1930s; the Jews who were refused entry as refugees into Canada in the $1930 \mathrm{~s}$ despite clear warning signs of expected prosecution under Nazi Europe; the Japanese who were thrown into internment camps during World War II and asked to return to Japan after the War despite the fact that most were born in Canada; and Blacks up until 1955 ("Not our proudest moments" 7-9; Cohen 84). Canada's strikingly racist immigrant record stretches this country's struggle with diversity to the beginning of its establishment ${ }^{2}$, and the history of the Canadian Muslim struggle, and Islamophobia, to well before 9/11. After World War II, due to Canadian immigration reforms, the country saw an influx of Muslim immigrants and has experienced an increase ever since (Kazemipur 24).

Today, the Muslim population in Canada has grown considerably. In 2006, there were 842, 200 Muslims in Canada, making up about 2.6 percent of the total population (Zine 6). In 2011, the population was placed at 940,000 , and by 2021, the number is expected to reach 2 million (Kazemipur 26). Most Canadian Muslims today live

${ }^{2}$ In 1947, then Prime Minister of Canada, William Lyon Mackenzie King said "The people of Canada do not wish, as a result of mass immigration, to make a fundamental alteration in the character of our population. Large-scale immigration from the Orient would change the fundamental composition of the Canadian population" (as cited in "Not our proudest moments" 9) which provides some indication on Canada's thoughts on immigration at the time and the reason for the racist and exclusionary immigration policies that existed then. 
in urban areas, with the majority, 61 percent, residing in Canada's largest province, Ontario, followed by Quebec at 19 percent, and finally British Columbia and Alberta at 10 percent each (Hanniman 272; Kazemipur 26). A large Muslim population is attributed to two factors: immigration and high fertility rates ${ }^{3}$ among the large child-bearing immigrant population (Kazemipur 26). In the late 199os, Muslims became the second-largest religious group in Canada, after Christianity (Zine 6). Today, Islam is Canada's fastest growing religion (6). These statistics show the pressing need to better incorporate Muslims into Canadian society.

In comparison to the rest of the country, Canadian Muslims are younger, with an average age of 28 in 2004, and 28.9 in $2013^{4}$ (Press). The Canadian Muslim population is also better educated, with 45 percent holding postsecondary degrees as compared to 25 percent in the rest of the country as of 2007 (Hanniman 272; Zine 8). Despite their education, however, they are less financially successful than other Canadians; in 2004, 14 percent of Muslims were unemployed compared to 7.4 percent in the rest of the country, and the most common employment for Muslim Canadians was in the sales and service industry which typically does not require high levels of education and promises a modest income (Hanniman 273). The Longitudinal Survey of Immigrants to Canada conducted by Statistics Canada in 2005 found that of all religious minority immigrant groups, Muslims claimed finding an adequate job as the most important difficulty since their arrival (over 40 percent) -the highest of any other minority religious group including other Eastern religions, Catholics, Protestants, and immigrants not claiming a religion (Kazemipur 132-133). Statistics from the same survey also show that Muslim immigrants' lower income levels are not affected by lower levels of education, language barriers or

3 More specifically on fertility rates, a 2013 study by two leading economist found that "immigrant women who have spent five years in Canada" have about twice as many young children as their native-born counterparts (Todd). Female immigrants from Africa, Pakistan, and India had the highest fertility rates and Middle Eastern female immigrants start off with high fertility rates, then taper off closer to the national average (Todd). In 2001, when the national fertility rate was 1.51 children per woman, Muslim women had an average fertility rate of 2.4 children born per woman followed by Hindu women at 2.0 children per woman and Sihk women at 1.8 children per woman (Todd; A Demographic Profile of Canada 5). Christian women and women with no faith had nearly identical fertility rates of 1.5 children per woman (Todd).

4 This data was prepared by the Statistics Canada National Household Survey which warned that data concerning small groups in the Survey, like new immigrants, may be "less reliable" because the rate of response for this voluntary survey is low for these groups (Press). foreign credential recognition; the reason behind Muslim economic and employment struggles is unclear (135). More recently, the 2016 Survey of Muslims in Canada shows that unemployment is still a worry for Muslims; 53 percent of respondents were very worried or somewhat worried about unemployment among Canadian Muslims, although it is important to note that this number has decreased since 2006 by 10 percent, especially among "men, older Muslims, those with the least education, and those who identified primarily as Muslim" (The Environics Institute 24).

Finally, the Canadian Muslim population today is extremely diverse, both ethnically and religiously; in 2008, "91 percent of Canadian Muslims were foreign born, [coming] from more than 30 countries" including South Asia, the Middle East and Arab world, the Caribbean, Europe, Africa, China, Afghanistan, Bosnia, Persia, and Turkey among many other countries (Hanniman 272; Zine 6). Canadian Muslims also come from a variety of religious and spiritual backgrounds including Shia, Sufi, and Ismaili sects, although Sunni Muslims make up the largest Islamic denomination in Canada (Zine 6). The diversity of the Canadian Muslim community, or rather, communities, is important when considering Muslim integration into the country.

The diversity of Muslim communities in Canada creates a minority within a minority complex which essentially means that the nearly one million Muslims living in Canada today are not a singular, homogenous group with the same ideals and goals for the future, or in the case of sects, that they even follow exactly the same religious practices or that they hold identical beliefs or opinions, even within the same sect. It is no surprise then that within the integration debate, Muslims themselves hold a variety of opinions; there are Muslims that believe that integration into Western society is religiously abhorrent, and others that believe in absolute assimilation, and yet others that believe in an integration that allows them to be both fully Canadian and fully Muslim (Ramadan, Western Muslims 2530). Although Canadian Muslim diversity is something to be celebrated and indeed provides the Muslim Canadian community with a variety of rich experiences and perspectives from which to draw and consult, it also complicates the Muslim integration process because it is unlikely that any single policy or solution moving forward will satisfy all Canadian Muslims. In light of these facts, it is important to note that this paper supports Muslim integration into Canadian society, and based on the 2016 Survey of Muslims in Canada where 72 percent of Muslims consider being Muslim and being Canadian as very important parts of their identity, integration, as opposed to 
separation, seems to be a popular option ${ }^{5}$ (The Environics Institute 15).

Despite the many opportunities the Canadian Muslim community has to offer - the large population, their robust education, their enormous economic potential, and their religious and cultural diversity - there are several obstacles that prevent Muslims from fully participating and integrating into Canadian society.

\section{Muslim Canadians and the Canadian Mosaic: The Issues at Hand}

The discussion of Muslim integration in Canada, and immigrant integration in general, is complex and multilayered. Although the potential for peaceful coexistence and harmonious integration exists, there are a few concerns that are specific to the Muslim population that must first be examined and addressed.

\section{Issue \# 1: Understanding Canadian Muslim Diaspora}

A large number of Canadian Muslims are living in what some scholars have termed "the Canadian Muslim diaspora," a concept that must be examined in order to understand Muslim immigrant experiences in Canada, and how these experiences affect integration (Zine 2-4i Moghissi, Rahnema, and Goodman 3-17). In its most general sense, diaspora "describes postmodern migrant communities that have resettled outside their ancestral homelands due to a variety of social, economic, and political factors" (Zine 3). This fits the description of the majority of Canadian Muslims, as they are mainly first- or second- generation immigrants, which also means that they are only in the beginning stages of the integration process (Kazemipur 15, 192-193).

In order for the process of integration to work, the immigrant population should more or less harmoniously adapt to the new society, ideally "reinventing the narrative of 'home' and recapturing feelings of familiarity and belonging" in the host country (Zine 3). The failure of developing these strong positive feelings towards the host country "creates deep social and psychological tensions that can be difficult to reconcile" (3). Typically, the integration process results in a fusion of the cultures in

${ }^{5}$ Of the 72 percent who believed being Muslim and being Canadian were both important parts of their identities, 50 percent placed greater importance on their Muslim identity, 15 percent placed greater importance on their Canadian identity, and 27 percent placed equal importance on both identities; the last statistic increased by 11 percent since the last Survey of Muslims in Canada conducted in 2006 by The Environics Institute (The Envrionics Institute 15). contact, namely, the immigrant and dominant cultures, but this usually happens at the expense of unequal power relations (3); new groups tend to be marginalized due to their ethnicity, culture or race (Moghissi, Rahnema, and Goodman 6). A Canadian "vertical mosaic" appears where immigrant, and often indigenous communities, are treated as second-class citizens above which European, white settlers dominate the demographic and cultural scene (Zine 4). As a result, "feelings of 'not belonging,' of being an exile or suffering as a psychological outsider" begin to surface and the integration process is interrupted and delayed (Moghissi, Rahnema, and Goodman 5; Zine 4). Therefore, instead of feeling a sense of belonging and attachment to Canada, Muslims experience "romantic longings for the homeland [which] are believed to compromise loyalty and kinship with [their] adopted society" further distancing Muslim immigrants from mainstream society and propelling the argument that multiculturalism is a failed project and assimilation is the only way for newcomers to integrate (Zine 4).

To add to the confusion, the popular image of "Islam as a well-spring of backwardness and religious fanaticism, hateful of women," freedom and democracy is a root cause of the marginalization of Muslim immigrants (Moghissi, Rahnema, and Goodman 13). Muslims increasingly and collectively may feel like they do not belong in Canada, not because these accusations are true (see Issue \#2: Conflicts Between Islamic and Western Values for more on this), but because their Islamic faith "[becomes] a permanent target for stereotyping and bigotry" (13). In these cases, feelings of not belonging can cause Muslim Canadians to live or continue living in isolation and marginalization with no interest of integrating into the larger community that they feel misunderstands and dislikes them.

There is reason to believe that, recently, fears of a marginalized Canadian Muslim diaspora do not pose a significant worry. The 2016 Survey of Muslims in Canada by The Environics Institute found that a majority 55 percent of those surveyed have a very strong sense of belonging to Canada, 39 percent had a generally strong sense of belonging to Canada and only 3 percent had a generally weak or very weak sense of belonging to Canada (The Environics Institute 9). Furthermore, a striking 58 percent stated that their sense of belonging to Canada has become stronger in the last five years while only 5 percent stated that their sense of belonging to Canada has weakened (The Envrionics Institute 9).

\section{Issue \#2: Conflicts Between Islamic and Western Values \\ One of the barriers to Muslim integration in Canada is the supposed contradiction between Islamic and}


Western values. Brought to prominence in 1996 by Samuel Huntington in his book The Clash of Civilizations, Huntington suggests that there are inevitable tensions between Muslims and non-Muslims that will rise everywhere in the post-Cold War era (Kazemipur 3). The incompatibility of Islam and the West is often framed within a context where Islam, in its entirety, is accused of being "illiberal, violent and non-compromising" while the West is "democratic, liberal and tolerant" (19). This dichotomy between Islam and the West is very problematic, especially because it assumes, for one, that all Muslims are the same, a gross miscalculation when considering the diversity of Muslim communities discussed earlier, and secondly, it reduces complex, multi-layered issues, like patriarchy and terrorism for example, to a single factor — Islam — despite the fact that these complicated social problems affect many societies, including Western ones (19).

To further complicate matters, some Western scholars find it nearly impossible to reconcile Islamic and Western ideologies because of Islam's complicated stance on secularism (21). Secularism is "the separation of religion and state" and the Western democratic answer to religion in the modern world (21). The conclusion is made that secularism is not compatible with Islam because Islam "does not allow for an easy separation between the spiritual and the mundane" or material world, which falls within the secular domain (21).

The issue of secularism and the contradiction between Islamic and Western values has led to the concept of "Muslim exceptionalism" in the Western democratic, and specifically, the Canadian multicultural context (5). Muslim exceptionalism stems from the belief of the inherent inability of Islam, and by extension Muslims, to integrate into Western or Canadian society because of the foundational and contradictory differences between them; where all other cultures can integrate seamlessly into the Canadian mosaic, Islam becomes the only culture that cannot, thus proving why multiculturalism is a failed political investment (7).

Meanwhile, Muslims do not deny that there are tensions between their Islamic and Western identities. Tariq Ramadan, a European Muslim philosopher and intellectual describes this dilemma stating:

To be a Muslim man or woman in the West while trying to respect one's values and principles is not easy. To maintain a spiritual life, carry out the ritual obligations... and keep to an ethical way of life is a daily test. All Muslims who are committed to their religion know this and experience it (Western Muslims 217).

By the same token, however, Muslims also believe that Islam's message is a universal or transcendent one in the sense that Islamic values and practices are applicable to all Muslims regardless of time, society, culture or geographic location, and without imposition on already existing cultures (Ramadan, Western Muslims 218; Abd-Allah 347, 363). As Dr. Umar Faruq Abd-Allah, a Muslim scholar based in the United States, writes in his essay "Islam and the Cultural Imperative" Islam has sought to integrate into every culture with which it has come into contact:

For centuries, Islamic civilization harmonized indigenous forms of cultural expression with the universal norms of its sacred law... In history, Islam showed itself to be culturally friendly...In China, Islam looked Chinese; in Mali, it looked African. Sustained cultural relevance to distinct people, diverse places, and different times underlay Islam's long success as a global civilization (347).

Ramadan also supports this view, stating:

The Sharia ${ }^{6}$, teaches us [Muslims] to integrate everything that is not against an established principle [in Islam] and to consider it as our own. This is, after all, the true universality of Islam: it consists in this principle of integrating the good, from wherever it may come, which has made it possible for Muslims to settle in, and make their own, without contradiction, almost all the cultures of the countries in which they have established themselves, from South America to Asia, through West and North Africa. It should not be otherwise in the West (Western Muslims 54 [emphasis in original]).

As both Abd-Allah and Ramadan make clear, it is possible for Islam and Muslims to adapt and thrive in Canadian society, just as they have adapted and thrived in many other cultures and societies, centuries prior.

It is also important to note the universal values and principles contained within the Sharia are in fact shared by many other cultures and nations, including Western and modern ones, like Canada (Ramadan, What I Believe 3). Western values like justice, democracy, human rights and the rule of law are not alien to Islamic ethics and are in fact,

${ }^{6}$ We are living in a time where before describing what Islam is, we must describe what it is not. The Shariah, or The Way, is not, as it is commonly thought of, a call to chop of the hands of thieves and stone adulterers. The Sharia is, as Ramadan describes it, a Muslim's guide on "how to be and remain Muslim" (Ramadan, Western Muslims 31-32). To apply the Sharia in Muslim daily life is to practice daily prayers, fast, give charity and commit to Islamic ethics (Ramadan, Western Muslims 33). 
as many scholars point out, supported within the Islamic faith (Ramadan, "What the West Can Learn"; Esposito 112114). So, contrary to contemporary thought, stereotypical views of Islam as a backwards, misogynistic, violent and illiberal religion, incompatible with Western values, are simply not true. Instead of differences and contradictions between Islam and the West, similarities and common values are what should be explored and nurtured throughout the Canadian-Muslim integration process, if it is to succeed.

\section{Issue \#3: Islamophobia in Canada}

After 9/11, Canadian Muslims, once "long-time, peace-loving, contributing citizens and residents were [now] being viewed as potential enemies and terrorists by virtue of their race, ethnicity, and religion" (Hanniman 273). In other words, Islamphobia and Islamophobic attitudes were strengthened and Canadian Muslims had to learn how to handle and resist this type of discrimination (Hamdon 9). Formally, the term Islamophobia refers to "a fear or hatred of Islam [and Muslims] that translates into individual, ideological and systemic forms of oppression and discrimination" (as cited in Hamdon 33; Hanniman 273). Islamophobia begins with the "othering" of a group of people, in this case Muslims, and the subsequent stereotyping of this group in ways that are inferior, immoral and at times, non-human as a justification for the subjugation and ill treatment of the minority group (Perry and Poynting 4). First coined in the United States, the term Islamophobia has since spread to other Western countries which experienced a surge of attacks targeted at their Muslim populations (Hamdon 33). In Canada, Muslims have seen verbal abuse, physical assault, vandalism and other forms of property damage, media stereotyping, and heightened police and government surveillance of Muslims and Muslim communities in the years after 9/11 (Moghissi, Rahnema, and Goodman xii; Hanniman 273). A 2002 study by the Canadian Council on American-Islamic Relations found that 60 percent of Muslims reported at least some experience with discrimination after $9 / 11$; the same survey also found that one third of respondents believed their lives had worsened after the 9/11 attacks (Perry and Poynting 34). In 2016, the Survey of Muslims in Canada found that 30 percent of Muslims experienced discrimination based on their religion, culture or ethnicity in the last five years, the same percentage reported by Muslims in $2006^{7}$ (The Environics Institute 38). Although this data suggests a significant decrease in discrimination since the 2002 study,

\footnotetext{
7 The study also found that the most common places where discrimination occurred were "the workplace, public spaces, retail establishments and schools and universities" (The Environics Institute 38).
}

a third of Canadian Muslims reporting discrimination is still an unfortunately significant amount; further, the fact that this number has not decreased in ten years is worrying. The 2016 Survey of Muslims in Canada also found that over a third (35 percent) of respondents identified mistreatment or discrimination of Muslims by the broader community as the most important issue facing local Muslim communities today, the most common concern identified by far, especially by women, those that were born in Canada, those between the ages of 18 and 34, and those that identified primarily as Muslim (The Environics Institute 22).

Islamophobic policies have also found their way into Canadian politics. The proposed niqab (face veil) ban in Quebec has received special political attention and media coverage. Bill 94 was introduced in the National Assembly of Quebec in 2010, creating considerable controversy (Cader and Kassamali; Sharify-Funk 136; Zine 9). The Bill proposed to "deny essential government services, public employment, education, and health care to Muslim women who wear [the] niqab" in Quebec (Cader and Kassamali). Bill supporters site two main reasons for the Bill's importance: first, that religious accommodation cannot compromise security and identification which the face veil would threaten (but which niqab-wearing women already stated they have no problem removing in either case) and second for "the need to protect "Quebec values" especially gender equality and secularism" (Sharify-Funk 143, 153). The latter point is, not surprisingly, rooted in the Islam versus the West debate with proponents of the Bill claiming that the niqab is a symbol of male misogyny in Islam and banning it would ensure the freedom of Muslim women (Zine 12-13). Of course, these claims are unreasonable and misinformed, based on widespread and misleading stereotypes of Islam and Muslims which have now evidently pervaded not only our media but also our political institutions.

Owing to the diverse opinions and perspectives within Canadian Muslim communities, some Muslims supported the Bill, among them, the Muslim Canadian Congress which in fact initiated the ban in 2009 with the reasoning that because the niqab is not a religious requirement, banning it does not violate any religious rights and freedoms guaranteed under the Canadian Charter (Zine 15). Although theologically this argument has some merit, namely that it is debatable whether or not the niqab is a religious obligation in Islam, the fact that a Muslim woman in Canada believes it is her religious duty to don the face veil and thus chooses to wear it, thereby exercising her right to religious freedom and expression, deserves the respect of her fellow Canadians and is entitled to the accommodation of her government. Religious expression, whether or not we personally like or agree with it, is a legally protected

University of Saskatchewan Undegraduate Research Journal 
constitutional right as is the right to reasonable accommodation $^{8}$ under the Canadian Charter of Rights and Freedoms, the Canadian Human Rights Act, and other provincial human rights codes (Zine 15; Sharify-Funk 148; Barnett, Nicol \& Walker 2).

What is more concerning than the Bill itself, however, is the large public support it received. Polls conducted by Angus Reid at the time of the Bill's proposition revealed that 95 percent of Quebecers and 75 percent of other Canadians supported the Bill (Zine 15; Sharify-Funk 143). Despite the strong public support to Bill 94, there was also strong opposition and criticism which is likely why the Bill was eventually suspended (Sharfy-Funk 136). Opponents of the Bill included Muslims and nonMuslims, men and women, niqabis and non-niqabis, "religious groups, academics, and civil society organizations" including Women's Rights groups, the Canadian Muslim Federation, the Quebec Jewish Congress and the No/Non Bill 94 Coalition (Shargy-Funk 136, 148-49). These opponents question the Bill's constitutionality, especially as it violates the right to religious freedom which is guaranteed by all of the Universal Declaration of Human Rights, the Canadian Charter of Rights and Freedoms, and the Quebec Charter of Human Rights. The Bill's gender equality reasonings have also been criticized; opponents question how the Bill achieves equality if certain women are being treated unequally (by being barred from accessing social services) because of their choice of dress, and why women's bodies, choices and wardrobes have become subject to government control in the first place (Shary-Funk 150-51). Opponents further criticize the Bill's impacts saying that a ban will isolate as oppose to integrate Muslim women who wear the niqab. This criticism is especially relevant to Quebec, the province that commissioned the BouchardTaylor report on reasonable accommodation regarding cultural practices, which had as one of its conclusions: "the way to overcome Islamophobia... 'is to draw closer to Muslims, not to shun them,'"' (as cited in Shary-Funk 152). Opponents also claim the Bill is Islamophobic because it targets Muslim women and Islamic practices specifically; opponents fear that this Islamophobic rhetoric is why the Bill has been widely supported (Shary-Funk 148). Although there is widespread support for Bill 94 , opposition towards the Bill does show that many Canadians still believe in a liberal, multicultural and inclusive Canada where all people,

8 The Canadian Human Rights Act states "in very broad and general terms in section 2 that the purpose of the Act includes: the principle that all individuals should have an opportunity equal with other individuals to make for themselves the lives that they are able and wish to have and to have their needs accommodated...without being hindered in or prevented from doing so by discriminatory practices..." (as cited in Barnett, Nicol \& Walker 2). including Muslims, can belong regardless of their choice of dress or religious convictions.

Political fascination with the niqab has continued after Bill 94, most notably during the 2015 Canadian political election where the niqab made headlines and made it onto party platforms. Centred on Zunera Ishaq's Federal Court of Appeal case to wear her niqab during a citizenship ceremony, the Conservative government, holding power at the time, cited their belief in Canadian values of openness and equality to promote a federal ban on the veil during citizenship ceremonies (Paperny \& Russell). When the court ruled in favour of Ishaq and against the government on the niqab ban, Conservative spokesperson Stephen Lecce promised the party would stay committed to its position by introducing a bill that would "require one to show their face while swearing the Oath of Citizenship" within 100 days of their reelection (Paperny \& Russell). Meanwhile, both Liberal Party leader Justin Trudeau, now Prime Minister of the country, and New Democratic Party (NDP) leader Tom Mulcair opposed the Conservative's ban on the niqab, although Mulcair stated that he was not "pro-niqab" and confessed that the niqab made him feel "uncomfortable" (Gollom; "Niqab position"). Additionally, both the Liberals and the NDP had members of their parties express individual "opposition to the niqab" ("Niqab position"). All the while, Muslims were concerned by the "racist and xenophobic anti-Muslim sentiment" the niqab debate had garnered, especially after attacks on Muslim women occurred surrounding the time of the controversy (Paperny \& Russell).

Islamophobia in Canada is one issue that is especially significant for Muslims today. Although statistics show that Islamophobia is slowly decreasing, it poses a large threat to Muslim-Canadian integration, and yet, it is through integration and dialogue that Islamophobia can decrease and eventually end.

\section{Moving Forward: Solutions Towards Muslim Integration}

First, it is important to note there are a variety of factors that affect the way in which Muslims can integrate into Canadian society. "The larger the size and the longer the history of the Muslim population in a receiving country, the greater its internal homogeneity and politicization, and the more tolerant and pluralist the new country's policies and practices are, the more cohesive, more visible, and more demanding is the [Muslim] community" and the more successful it is at integrating smoothly into mainstream society (Moghissi, Rahnema, and Goodman 8).

There are several types of integration models ranging from assimilation, which places the responsibility of integration on the minority population to learn, adapt and 
take part in the majority's culture ${ }^{9}$, to more liberal views where the responsibility of integration is placed on the host society, who is expected to learn and respect minority cultures and legally recognize and protect these rights (Kazemipur 31). The "inter-cultural" approach, which is the focus of this paper, places responsibility on both the minority and host populations and encourages dialogue and understanding from both sides (Kazemipur 31).

In addition to an approach that engages both sides, "the true measure of integration" according to Abdolmohammad Kazemipur, author of The Muslim Question in Canada, is the "emotional attachment" of minorities to their host societies which ensures the faithfulness and loyalty of immigrants to the broader society (Kazemipur 32). In the case of Canadian-Muslim integration, Muslims' emotional connection to Canada creates a win-win scenario for both Muslim Canadians and Canadian society; Muslims develop a sense of belonging to Canada and Canada benefits from the loyalty of its Muslim citizens. The question now is what will this two-way integration model look like?

The inter-cultural integration model is a two-party process between the minority community, in this case the Muslim community, and the host society, in this case, the Canadian people and government. In order for integration to occur successfully, both parties must contribute to the process. There are numerous policy suggestions that can be listed here, and a few are mentioned below by means of example, but more valuable than an exhaustive list of recommendations is a general model that Muslim communities, policy makers and the Canadian public can use, modify and expand as they see fit.

\section{Making Home: Muslims' Guide to Integration in Canada}

The vision for the future of Muslims in Canada is one where Islam is normalized into Canadian mainstream society, the practices of its adherents acknowledged and respected, and the interactions between Muslims and other Canadians are based on peaceful coexistence and mutual respect and understanding. The vision for the future of Muslims in Canada is also one where Canadian Muslims feel that they belong, that they are valued, and where there is space for them to contribute to Canadian culture, history and society.

9 In the assimilation model, minority or immigrant populations are expected not only to learn the dominant language, culture and history of the host population, but also to "[participate] in the political and civic life of the host societies, subscribing to the majority's work ethic, and taking responsibility for one's economic life without relying on the financial support of the host government" (Kazemiur 31).
For Muslims, the road to integration is a two-step process, beginning with adaptation. Where they can, Muslims should enjoy and participate in every aspect of Canadian life that does not go against core Islamic principles. The argument here is that Muslims can "integrate into [their] identity and [their] culture everything humankind produces that is not in contradiction with a prohibition" which includes much of the Canadian culture (Ramadan, Western Muslims 220). Where uncertainties arise, the re-examination of Islamic texts and rulings and their alteration in order to better address modern needs without changing the fundamentals of the religion itself are needed (Kazemipur 43). This form of theological and religious dialogue occurs amongst scholars in the field of figh al-aqalliyyat or the jurisprudence of minorities by a process known as ijtihad or creative thinking (Kazemipur 40-42). This process allows Muslims to accommodate, from within their religion, rulings to better fit the cultural contexts in which they live, again without changing core Islamic principles, beliefs and practices (Kazemipur 40-42; Ramadan 53). To give a simple example, the subject of music in Islam is highly contested, with some scholars proclaiming its prohibition and others, its acceptance (Ramadan, Western Muslims 220). In order to live a more relaxed presence in Canada where music is part of daily life, those scholarly views that permit listening to music, with "certain conditions concerning respect for ethical values" would be deemed a more appropriate ruling for Canadian Muslims than those views that prohibit it all together (220). The idea behind these modifications is to allow Muslims to practice their religion with more ease in Canada (Kazemipur 41-43; Ramadan 53). Of course, where Islamic principles are not in agreement with Canadian culture, government accommodation is required; this issue is discussed in the next section.

The second step to the Muslim integration process is the creation and production of a distinct, customized Canadian-Islamic identity "by fashioning an integrated cultural identity that is comfortable with itself and functions naturally in the world around it" (Abd-Allah 369). Essentially, what will be produced is a distinctly Canadian understanding of Islam, one that is "indigenous-not in the sense of losing identity through total assimilation...-but in the word's original sense, namely, being natural, envisioned, and born from within" (Abd-Allah 369). This "reform movement" requires first the empowerment of Muslims who need to "stop considering [themselves] a marginalized minority," to become active and productive citizens who fully participate in their societies, as both Canadians and Muslims. Muslims need to build deeply rooted Muslim-Canadian cultures and identities here in Canada (Ramadan, Western Muslims 224 -225).

From a policy perspective, funding to encourage this type of culture-creation within Muslim communities in 
Canada is vital, as is the development of Canadian-Islamic scholarship, which would establish rigorous educational programs that train young Canadian Muslims to understand Islam in the context of Canadian society and develop an Islamic identity that looks and feels Canadian. Empowerment programs within the Muslim community where issues of Islamophobia, marginalization and victimization are discussed and attempts at their resolution occur is also important to better allow Muslims to engage and participate in their communities. Beyond this, Canada's role in Muslim integration becomes the accommodation of those things that cannot be compromised by the Islamic religion, like prayer, fasting, the hijab or headscarf, the niqab, and religious prohibitions, for example.

\section{A Place to Call Home: The Government's Role in Muslim Integration}

On the government side, the two-way approach to integration places the responsibility of accommodation and learning on the host societies, particularly governments, which inform public policy, and institutions like schools and workplaces (Kazemipur 31). This method may be referred to as the "politics of recognition", a term introduced by Charles Taylor in the 1990s (Kazemipur 39). Taylor's theories introduced unique concepts like "the recognition of one's cultural and ethnic heritage as a part of one's human rights" (39). Thus, "the minority has a right to keep its cultural heritage and the majority is expected to educate itself about minority cultures," in the form of multicultural and anti-racist curricula and anti-discriminatory workplace policies, for example (Kazemipur 31). The most notable criticism of a politics of recognition infers that because "policies revolving around the recognition of minorities...results in a less stressful and more comfortable environment for those minorities," this "comfort does not necessarily result in a stronger sense of identification with Canada" and "may indeed work in the opposite direction that is, it may very well strengthen minority identity at the expense of national identity; ${ }^{\prime \prime}$ this would be, antithetical to the true goal of integration which is to create an emotional attachment between the immigrant and host society (Kazemipur 40). If Muslim Canadians complete their part of the integration process, namely first to adapt to Canadian culture as much as their religion allows, and then to create their own distinct Canadian-Muslim identities, the negative impacts of a politics of recognition can be curtailed.

The politics of recognition approach is already very popular in Canada and has proven to be extremely successful; the approach produced multicultural policies of which Canada was the first country in the world to adopt and implement (Kazemipur 5-6). These multicultural policies then gave birth to the "Canadian mosaic" concept. Coined by John Murray Gibbon in the 1930s, Canada was deemed to be "a 'mosaic' of cultural pieces, each piece separate and distinct, each engaging the others in mutual respect, each retaining its own identity yet each contributing to the country as a whole" (Dryden 199). It is because of Canada's understanding and more tolerant nature that Muslims for the most part, feel so at home here; that between 73 and 99 percent of Muslim immigrants, when asked to describe their identities state they are either proud or very proud to be Canadian (Zine 7). There is still more work to be done however; proposals for niqab bans in Quebec and the rise of Islamophobia and anti-Muslim hate crimes in Canada are reasons for deep concern requiring work to be invested for a better future.

The most important thing that politicians, policy makers, the government and the public should know about Muslim integration into Canadian society is that the Muslim identity requires time and space to grow and develop (Ramadan, Western Muslims 79). "To cut Muslims off from [the fundamental aspects of faith] is to cut them off from their very being" (Ramadan, Western Muslims 79). The fundamental aspects of faith - salah or prayer, sawm or fasting, zakat or charity giving, and hajj or the sacred pilgrimage to Mecca - need to be respected and accommodated to ensure that the Muslim faith and identity is not destroyed (Yousif 29-30; Ramadan Western Muslims 79).

Take salah for instance. Muslims pray up to five times a day, but many Muslims, unable to find a clean, quiet place in which to perform their prayers, either do not pray or resort to praying awkwardly in a public space (Yousif 3234). If there was a general understanding of the requirements of the Muslim prayer amongst the Canadian public however, and a policy requiring public places like universities, airports and libraries to have clean and quiet spaces where prayers can be performed, or at least the ability to provide this space when the occasion arises, salah, and thus being a Muslim in Canada, becomes much easier.

Those things which Muslims deem haram or impermissible, like the consumption of alcohol and pork products and interaction with riba or bank interest should also be acknowledged and accommodated as much as possible (Yousif 57). In Canada, drinking is a common and widespread social activity, one that is often associated with celebration and social interaction (59-60). Drinking and places where alcohol is served may be uncomfortable for some Muslims, often leading to their exclusion from many social events which in turn reduces their opportunities to bond and interact with the wider Canadian community (Kazemipur 170). Some Muslim scholars including Yousef alGharzawi, a supporter of figh al-aqalliyyat, suggests Muslims use ijtihad or creative thinking when asking 
"questions related to working in places in which pork and alcohol are served, or opening a business that would have to sell those products, or accepting invitations to attend parties in which pork and alcohol are consumed" with the understanding that drinking is a social reality in Western culture and that Muslim participation in Canadian social activities is important to their overall integration and sense of belonging to the country (Kazemipur 41). Meanwhile, the broader Canadian society can also consider whether serving alcohol only at specific times and locations during an event, for example, or hosting alcohol-free social events to ensure that Muslims can participate would be possible in order to culturally accommodate Muslims and further encourage their participation in social events.

The two-way integration system creates understanding, respect and mutual compromise on both sides of the integration process (Kazemipur 31). The acknowledgement of Muslim needs and accommodations by the government and other Canadians coupled with the religious reforms Muslims in Canada should undergo, and the need to create a distinct Canadian-Muslim identity and culture, is a way toward Canadian Muslim integration. A smooth integration will clear misconceptions about the Islamic faith, remove the issue of Muslim marginalization, and reduce and hopefully end Islamophobia in Canada.

\section{Final Thoughts on Canadian Muslim Integration}

Like so many others, I am a Canadian Muslim who feels no contradiction between her Islamic and Canadian identities; on the contrary, I believe my deeply rooted values of freedom, democracy and multiculturalism are reinforced by both my religious and cultural identities.

I also believe the way forward for Canadian Muslims, and Canada as a whole, is to engage in a two-way inter-cultural process where both parties engage in respectful dialogue and discussion on topics of faith, tolerance and accommodation. What should stay and what will go in a distinct Canadian Islam? How far will Canada go to accommodate these cultural and religious differences? That is up to Muslims and Canadians to decide for themselves as they move forward and make the future of Canada.

A 2006 survey by The Environics Institute revealed that a majority (55 percent) of Muslims expressed being somewhat or very worried about the future of Muslims in Canada (Kazemipur 108-109). In 2016, The Environics Institute found that opinions on the future were mixed among the Muslims surveyed, with 35 percent believing the next generation will face more discrimination than today. This belief was most prevalent among Canadian-born Muslims where 50 percent expected more discrimination - a worrying number indeed (The Environics 37). The same study found however that an astounding 90 percent of Muslims surveyed were optimistic that a new majority Liberal government led by Prime Minister Justin Trudeau would improve Muslim-Canadian relations, which is cause for some hope and celebration and demonstrates the important role politics can play in Canadian-Muslim integration (The Environics 37).

Like the majority of Muslims, I am optimistic about the future of Muslims in Canada; despite the many wellintentioned warnings coming from scholars and intellectuals about the hardships Muslims will face in the years to come:

Prejudices, racism, and Islamophobia are tangible expressions of the hard reality of Western societies, and Muslims must not naively think that these will simply disappear as they become citizens settled in their societies. Increasingly, and for a considerable period, they will have to become accustomed to facing political security measures, discrimination, accusations of "doubletalk," menacing, malevolent looks, and acts of surveillance and control (Ramadan, Western Muslims 226).

I refuse to let this be my reality or my Canada; I refuse to succumb to the victim mentality where I live in a world inside my head, where I believe the world is attacking my identity as a Muslim and as a Canadian. I believe Canada will change for the better and the delicate mosaic it has handed to the Muslims community will be restored through our collective efforts as tolerant, respectful, peace-loving Canadians.

\section{Post Script: Canada at a Crossroads - The Quebec Mosque Shooting \& Motion 103}

In light of recent events in Canada, the question of MuslimCanadian integration has become ever-more pressing, timely and important. These recent events have shown similar patterns to past episodes of Muslim-Canadian integration attempts (recall: the niqab debate in the 2015 Canadian election). This shows that Canada is still grappling with the diversity and differences Muslims pose as a collective community in this country.

There are really two sides to the the Muslim question in Canada. On one side, democracy-loving, openminded, multicultural Canadians are welcoming of Muslims and their ways, prepared to protect their rights and freedoms to religious and cultural expression, so long as it does not interfere with the rights and freedoms of others. 
On the other hand, there are some Canadians, and a rising political right, that still fear and misunderstand Islam and Muslims and that believe Islamic values are at odds with Western, modern and Canadians ones. We saw this in the aftermath of the Quebec shooting, where an overwhelming majority of Canadians and politicians immediately showed their solidarity and sincere support to the Muslim community in the wake of what several politicians, including Prime Minister Justin Trudeau, called a terrorist attack against the Muslim community in Canada (CBS \& The Associated Press). There was reaffirmation from politicians at vigils across the country that Muslims were just as Canadian as anyone else, that they belonged and were welcomed here, and most of all, that they would be protected. And still, there were some Canadians who did not support this message and instead organized a protest to ban Islam and Muslims in front of Masjid Toronto, to the sharp criticism of several Canadians, including Toronto Mayor John Tory (Nasser \& McLaughlin).

Islamophobia in Canada, especially in the wake of the Quebec shootings, has also garnered political attention and action with Motion 103 which calls on the Canadian government to "[reduce] or [eliminate] systemic racism and religious discrimination, including Islamophobia" and present a report for affected communities within 240 calendar days (Harris "Conservatives wrestle"). Several politicians and members of the public have backed the motion, including the NDP and Prime Minister Justin Trudeau, but the motion has also met opposition by some Conservative politicians, including Saskatchewan's David Anderson who wanted to see the word "Islamophobia" removed from the motion after claiming that is was vague and undefined. Conservative leadership candidate Kellie Leitch has been very vocal about her opposition to the motion on social media and started a petition to stop the motion believing that no religion should receive special privileges (Harris "Liberal MP"; Harris "Conservatives wrestle"). Conservative leadership candidate Pierre Lemieux also opposed the motion claiming that Islamophobia "is not a problem in Canada" - an insult to every Canadian Muslim who has experienced Islamophobia in Canada and a grossly insensitive remark in the wake of the Quebec mosque shooting that left six Muslims dead and several injured (Harris "Liberal MP"; CBS and The Associated Press).

The Canadian public has also voiced their opinion on the motion, many supporting it, and many opposing it for fear that an anti-Islamophobia motion would diminish freedom of speech, give special treatment to Islam and Muslims, and may lead to the spread of Sharia law (Harris "Conservatives wrestle").

Such is the nature of democracies. Democracies are platforms of open dialogue and debate on the most pressing issues affecting our nation. The question for
Muslims, and perhaps other minority groups in the future, is: which side will win. For Muslims right now, under a Trudeau government, the odds are likely tipping in their favour; politically, they are acknowledged, mentioned and welcomed and their rights are protected. Under a Conservative government with Trump-like-minded leaders like Kellie Leitch, political recognition that is positive and encouraging may not exist, although negative recognition most certainly will, and Muslim, and likely other minority, rights might be threatened. As usual, it will be up to the Canadian people to decide for themselves which Canada they want. 


\section{Bibliography}

A Demographic Profile of Canada. Canadian Council on Social Development. No date.

Abd-Allah, Umar Faruq. "Islam and the Cultural Imperative." CrossCurrents, vol. 56, no. 3, 2006, pp. 357-375.

Barnett Laura, Julia Nicol, and Julian Walker. An Examination of the Duty to Accommo date in the Canadian Human Rights Context. Library of Parliament, 2012.

Cader, Fathima and Sumayya Kassamali. "Islamophobia in Canada: A Primer." New Socialist: Ideas for Radical Change. New Socialist Group, 01 Feb. 2012. Web. 01 April 2015.

CBS and The Associated Press. "New info on Quebec mosque attack suspect." CBS News, 30 Jan. 2017, http://www.cbsnews.com/news/quebec-mosqueterrorist-attack-muslims-justin-trudeau-donaldtrump-no-comment/. Accessed 1 Apr. 2017.

Cohen, Rina. "A Brief History of Racism in Immigration Policies for Recuring Domestics." Canadian Woman Studeis/Les Cahiers De La Femme, vol. 14, no. 2, 1994, pp. 83-86.

Dryden, Ken. "Becoming Canada." Becoming Canada. McClelland \& Stewart, 2010. 183-201.

Esposito, John L. "Where are the Reformers?" The Future of Islam. Oxford University Press, 2010, pp. 88 - 141.

Geddes, John. "Canadian anti-Muslim sentiment is rising, disturbing new poll reveals." Maclean's. Roger's Media, 03 Oct. 2013. Web. 12 March 2015.

Gollom, Mark. "Trudeau, Mulcair go on the offensive over niqab issue in 2nd French-language debate." CBC News, 2 Oct. 2015, www.cbc.ca/news/politics/frenchlanguage-debate-party-leaders-quebec-1.3255075. Accessed 1 Apr. 2017.

Hamdon, Evelyn Leslie. Islamophobia and the Question of Muslim Identity. Fernwood Publishing, 2010.

Hanniman, Wayne. "Canadian Muslims, Islamophobia and national security." International Journal of Law, Crime and Justice 36 (2008): 271-286. Web. 15 March 2015.
Harris, Kathleen. "Conservatives wrestle over Liber MP's anti-Islamopbobia motion." CBC News, 14 Feb. 2017, www.cbc.ca/news/politics/islamophobia-m103-khalidmotion-1.3982013. Accessed 7 Mar. 2017.

_ "'Liberal MP won't remove Islamophobia reference from motion condemning discrimination." CBC News, 15 Feb. 2017, www.cbc.ca/news/politics/m103islamophobia-joly-khalid-1.3983911. Accessed 7 Mar. 2017.

Kazemipur, Abdolmohammad. The Muslim Question in Canada: A Story of Segmented Integration. UBC Press, 2014 .

McLaughlin, Amara, and Shanifa Nasser. "Protesters outside Masjid Toronto call for ban on Islam as Muslims pray inside." CBC News, 18 Feb 2017, www.cbc.ca/beta/news/canada/toronto/anti-muslimprotest-masjid-toronto-1.3988906. Accessed 18 Mar. 2017.

Moghissi, Haideh, Saeed Rahnema and Mark J. Goodman. Diaspora by Design: Muslim in Canada and Beyond. University of Toronto Press, 2009.

"Niqab position of NDP and Liberals not shared by some Quebec candidates." CBC News, 30 Sep. 3015, www.cbc.ca/news/canada/montreal/canada-election2015-niqab-quebec-1.3250028. Accessed 1 Apr. 2017.

"Not our proudest moments. (The Immigrant ExperienceDiscrimination)." Canada and the World Backgrounder, vol. 68, no. 3, 2002, pp. 7-9.

Paperny, Anna Mehler, and Andrew Russell. "Court rejects fed' appeal for stay in niqab case." Global News, 5 Oct. 2015, globalnews.ca/news/2259905/court-rejects-fedsappeal-for-stay-in-niqab-case/. Accessed 1 April 2017.

Perry, Barbara and Scott Poynting. "Inspiring Islamophobia: Media and State targeting of Muslims in Canada since 9/11." TASA Conference 2006. University of Western Australia \& Murdoch University. (2006): 1-11. Web. 15 March 2015.

Press, Jordan. "Survey shows Muslim population is fastest growing religion in Canada." National Post, 8 May 2013, news.nationalpost.com/news/canada/surveyshows-muslim-population-is-fastest-growing-religionin-canada. Accessed 25 Mar. 2017.

The Environics Institute. Survey of Muslims in Canada 2016. The Environics Institute, 2016. 
Todd, Douglas. "High birthrate among immigrant women has implications for Canada." Vancouver Sun, 8 Aug. 2013, www.vancouversun.com/life/High+birthrate+among $+\mathrm{i}$ mmigrant+women+implications+Canada/8766093/sto ry.html. Accessed 27 Mar. 2017.

Ramadan, Tariq. Western Muslims and the Future of Islam. Oxford University Press, 2004.

—What I Believe. Oxford University Press, 2010.

- "What the West Can Learn From Islam." Tariq Ramadan, 14 Feb. 2007, tariqramadan.com/english/what-thewest-can-learn-from-islam/. Accessed 28 Mar. 2017.

Rehman, Saira and Oman Siddiqui. Muslim Students: Their Culture and Faith. Islamic Social Services Association, 2002.

Sharify-Funk, Meena. "Governing the Face Veil: Quebec's Bill 94 and the Transnational Politics of Women's Identity." International Journal of Canadian Studies/Revue internationale d'etudes canadiennes, no. 43, 2011, pp. 135-163.

Yousif, Ahmad F. Muslims in Canada: A Question of Identity. Legas, 1993.

Zine, Jasmine. "Introduction: Muslim Cultural Politics in the Canadian Hinterland." Islam in the Hinterlands: Muslim Cultural Politics in Canada. Ed. Jasmine Zine. UBC

Press, 2012. pp. 1-37. 
